\title{
The Effectiveness of Oxytocin and Marmet Massage on Increased Prolactin Hormone for Smooth Breastfeeding in Postpartum Mothers in Langsa City Health Office, Indonesia
}

\author{
Emilda Emilda $^{1 *}$, Juliastuti Juliastuti ${ }^{2}$ \\ ${ }^{1}$ Department of Midwifery, Ministry of Health, Polytechnic of Langsa, Aceh, Indonesia; ${ }^{2}$ Department of Midwifery, Polytechnic of \\ Health, Ministry of Health, Aceh, Indonesia
}

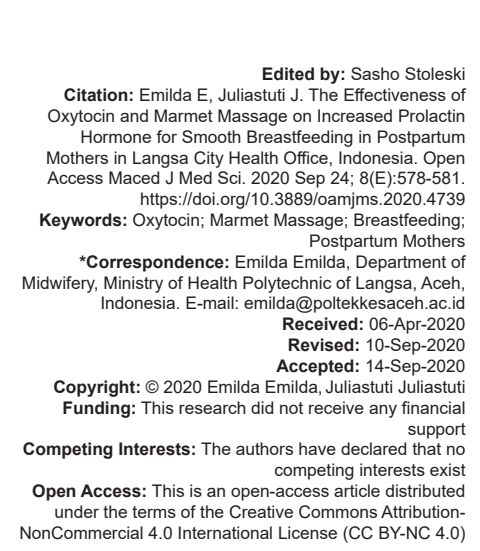

Introduction

The Government of Indonesia has established regulations regarding exclusive breastfeeding in the Republic of Indonesia Government Regulation No. 33/2012. Achievement of breastfeeding, especially exclusive breastfeeding in Indonesia, is still very low. Based on data from the 2018 Basic Health Research, mothers who exclusively breastfeeding for 6 months were only $37.3 \%$ and had not reached the national target of $80 \%$. One of the cities in Indonesia with exclusive low breastfeeding coverage is Langsa City, especially in Sungai Parit Health Center. Based on data from the Langsa City Health Office, there has been a decline in exclusive breastfeeding data from 2016 to 2018. In 2015 , the coverage of babies who were given exclusive breastfeeding was $66 \%$, in 2016 , the coverage data of babies given exclusive breastfeeding were $63.02 \%$ and in 2018 the coverage data for infants given exclusive breastfeeding were $62 \%$ [1].

\begin{abstract}
KGOUND: One of the causes of the disruption to the achievement of exclusive breastfeeding is the decrease This technique has been used by various people in the world for both medical treatment and health care.

on Pro purpose of this study was to analyze the differences in the effectiveness of Oxytocin and Marble Massage

METHODS: A quasi-experimental design method prospective cohort was used with no control group design. Giving oxytocin massage treatment and Mamet massage for prolactin hormone levels for smooth milk. The sample was selected of 32 postpartum mothers who were divided into two groups. The number of samples for each group was 16 and multivariate analysis. and the highest prolactin hormone level was $357.9 \mathrm{ng} / \mathrm{ml}$, the highest was $357.9 \mathrm{ng} / \mathrm{ml}$. The mean prolactin hormone level of the prolactin hormone by the oxytocin massage method was $195.6 \mathrm{ng} / \mathrm{ml}$ with Std. deviation $106.8 \mathrm{ng} / \mathrm{m}$ while the average method for Mamet massage is $538.9 \mathrm{ng} / \mathrm{ml}$ with Std. deviation $269.6 \mathrm{ng} / \mathrm{ml}$. The results of the can be concluded that there are significant differences between the oxytocin and Mamet massage methods.

CONCLUSION: There is a significant difference between the oxytocin massage method and Mamet to increase levels of the hormone prolactin in postpartum mothers.
\end{abstract}

Breastfeeding is influenced by several important factors including knowledge of maternal nutrition [2]. Breastfeeding is influenced by two factors, namely, macro- and micro-level factors [3]. Micro-level factors include traditions that believe that breast milk is not enough for babies and there is a need for additional formula milk to make babies full. Macro-level factors are social media that provide publications related to good formula milk for babies, thereby changing the perception of mothers to provide formula milk for babies. Provision of food or other drinks besides breast milk allows the baby to be exposed to pathogens thereby increasing the risk of infection and adversely affecting nutritional status [4].

Infants who are not exclusively breastfed have a high risk of malnutrition. Factors of milk production and expenditure in the body are influenced by two hormones, namely, prolactin and oxytocin. Decreased baby suction also decreases the stimulation of the hormones prolactin and oxytocin [5], [6]. One effort 
to increase the prolactin hormone was with massage techniques. Massage techniques have been used by various communities in the world for medicine and health [7], [8], [9]. Efforts to stimulate the hormone prolactin and oxytocin in mothers after childbirth can be done with oxytocin massage [10]. Oxytocin massage is a massage along the spine to the costae bone to stimulate the hormone prolactin and oxytocin after childbirth [11], [12].

This massage serves to increase the hormone oxytocin which can calm the mother so that milk automatically comes out. In this case, the researchers applied acupressure point for lactation and oxytocin massage techniques to provide cutaneous stimulation which was expected to increase patient comfort, stimulate oxytocin release resulting in increased milk production. How does the effectiveness of oxytocin and Mamet massage differ from the increase in the prolactin hormone for smooth milk in postpartum mothers in the Work Area of Langsa City Health Office?

\section{Methods}

The quasi-experimental design of a prospective cohort study with no control group design was used to analyze the data carried out at the Langsa City Health Center covering 5 Community Health Center units from July to December 2019. The population was all primigravida, postpartum mothers, in the 2019 Langsa City Health Office, while the sample was selected as many as 32 postpartum mothers who were divided into two groups. Data collection techniques were by interventions of oxytocin massage and Mamet massage and conducted laboratory tests assessing levels of the hormone prolactin. Data analysis used the T-independent test statistical approach for bivariate analysis and multivariate analysis.

Table 1: Characteristics of respondents by group of oxytocin massage methods and Mamet massage

\begin{tabular}{|c|c|c|}
\hline \multirow[t]{3}{*}{ Characteristics } & \multirow{2}{*}{\multicolumn{2}{|c|}{$\begin{array}{l}\text { Method group } \\
\text { Ocsitosin and Mamet massage } n=32\end{array}$}} \\
\hline & & \\
\hline & $f$ & $\%$ \\
\hline \multicolumn{3}{|l|}{ Mother age } \\
\hline $20-35$ years & 31 & 96,9 \\
\hline$>35$ years & 1 & 3,1 \\
\hline \multicolumn{3}{|l|}{ Mother weight } \\
\hline $48-55 \mathrm{~kg}$ & 5 & 15,6 \\
\hline $56-63 \mathrm{~kg}$ & 18 & 56,3 \\
\hline $64-71 \mathrm{~kg}$ & 9 & 28,1 \\
\hline \multicolumn{3}{|l|}{ Age of pregnancies } \\
\hline Normal: 36 s.d 40 weeks & 32 & 100 \\
\hline \multicolumn{3}{|l|}{ Education } \\
\hline Basic & 18 & 56,3 \\
\hline High school & 14 & 43,8 \\
\hline \multicolumn{3}{|l|}{ Occupation } \\
\hline Employed & 23 & 71,9 \\
\hline Unemployment & 9 & 28,1 \\
\hline \multicolumn{3}{|l|}{ Family incomes } \\
\hline Regional max wage & 18 & 56,3 \\
\hline$<$ Regional min wage & 14 & 43,8 \\
\hline \multicolumn{3}{|l|}{ The weight of new born } \\
\hline Normal weight new born $2.5 \mathrm{~s} . \mathrm{d} 4 \mathrm{~kg}$ & 32 & 100 \\
\hline
\end{tabular}

\section{Results}

\section{Univariate analysis}

Univariate analysis is performed to see the frequency distribution of the independent variables on the dependent variable. The univariate analysis seen in the independent variable is the frequency distribution of the prolactin hormone levels for smooth milk by the oxytocin and Mamet massage methods.

Characteristics of respondents by age, dominated by mothers aged 20-35 years (96.9\%), maternal body weight dominated by weight $56-63 \mathrm{~kg}$ $(56.3 \%)$, gestational age $100 \%$ in normal pregnancies 36-40 weeks, majority mother's education with $56.3 \%$ basic education, majority of mothers work $71.9 \%$, majority family income earning > regional max wage $56.3 \%$, and total infant birth weight $100 \%$ with normal birth weight babies 2.5-4 kg (Table 1). Data on the levels of the hormone prolactin for smooth milk by oxytocin massage method and Mamet massage are in shown Table 2:

Table 2: Distribution of respondents by frequency of prolactin hormone levels for smooth breastfeeding with the oxytocin massage method and marble massage

\begin{tabular}{|c|c|c|c|c|c|}
\hline \multicolumn{3}{|l|}{ Method } & \multicolumn{3}{|l|}{ Method } \\
\hline $\begin{array}{l}\text { Oxytocin } \\
\text { massage }\end{array}$ & Unit & $\mathrm{F} \%$ & $\begin{array}{l}\text { Marmet } \\
\text { massage }\end{array}$ & Unit & $\mathrm{F} \%$ \\
\hline 29.8 & $\mathrm{ng} / \mathrm{ml}$ & $1(6.3)$ & 160.9 & $\mathrm{ng} / \mathrm{ml}$ & 1 (6.3) \\
\hline 36.8 & $\mathrm{ng} / \mathrm{ml}$ & $1(6.3)$ & 203.4 & $\mathrm{ng} / \mathrm{ml}$ & $1(6.3)$ \\
\hline 38.0 & $\mathrm{ng} / \mathrm{ml}$ & $1(6.3)$ & 328.5 & $\mathrm{ng} / \mathrm{ml}$ & $1(6.3)$ \\
\hline 98.5 & $\mathrm{ng} / \mathrm{ml}$ & $1(6.3)$ & 338.6 & $\mathrm{ng} / \mathrm{ml}$ & $1(6.3)$ \\
\hline 149.7 & $\mathrm{ng} / \mathrm{ml}$ & $1(6.3)$ & 358.8 & $\mathrm{ng} / \mathrm{ml}$ & $1(6.3)$ \\
\hline 167.3 & $\mathrm{ng} / \mathrm{ml}$ & $1(6.3)$ & 359.8 & $\mathrm{ng} / \mathrm{ml}$ & $1(6.3)$ \\
\hline 176.3 & $\mathrm{ng} / \mathrm{ml}$ & $1(6.3)$ & 453.9 & $\mathrm{ng} / \mathrm{ml}$ & $1(6.3)$ \\
\hline 195.7 & $\mathrm{ng} / \mathrm{ml}$ & $1(6.3)$ & 462.5 & $\mathrm{ng} / \mathrm{ml}$ & $1(6.3)$ \\
\hline 203.5 & $\mathrm{ng} / \mathrm{ml}$ & $1(6.3)$ & 493.7 & $\mathrm{ng} / \mathrm{ml}$ & $1(6.3)$ \\
\hline 211.5 & $\mathrm{ng} / \mathrm{ml}$ & $1(6.3)$ & 568.5 & $\mathrm{ng} / \mathrm{ml}$ & $1(6.3)$ \\
\hline 249.5 & $\mathrm{ng} / \mathrm{ml}$ & $1(6.3)$ & 589.8 & $\mathrm{ng} / \mathrm{ml}$ & $1(6.3)$ \\
\hline 265.2 & $\mathrm{ng} / \mathrm{ml}$ & $1(6.3)$ & 657.9 & $\mathrm{ng} / \mathrm{ml}$ & $1(6.3)$ \\
\hline 293.1 & $\mathrm{ng} / \mathrm{ml}$ & $1(6.3)$ & 783.0 & $\mathrm{ng} / \mathrm{ml}$ & $1(6.3)$ \\
\hline 301.6 & $\mathrm{ng} / \mathrm{ml}$ & $1(6.3)$ & 827.0 & $\mathrm{ng} / \mathrm{ml}$ & $1(6.3)$ \\
\hline 356.7 & $\mathrm{ng} / \mathrm{ml}$ & $1(6.3)$ & 858.5 & $\mathrm{ng} / \mathrm{ml}$ & $1(6.3)$ \\
\hline 357.9 & $\mathrm{ng} / \mathrm{ml}$ & $1(6.3)$ & 1178.0 & $\mathrm{ng} / \mathrm{ml}$ & $1(6.3)$ \\
\hline
\end{tabular}

Respondents using oxytocin massage method with the highest prolactin hormone level were $357.9 \mathrm{ng} / \mathrm{ml}$ and the lowest prolactin hormone level was $29.8 \mathrm{ng} / \mathrm{ml}$, while respondents with the method of massage of the Mamet the highest prolactin hormone level was $1178.0 \mathrm{ng} / \mathrm{ml}$ and the lowest prolactin hormone level was $160.9 \mathrm{ng} / \mathrm{ml}$.

Table 3 shows that respondents with prolactin hormone levels with oxytocin massage method were $56.3 \%$, showing that most respondents with normal prolactin hormone levels were 9.7-208.5 ng/ml and respondents using the Mamet massage method by $87.5 \%$, indicating that the majority of respondents with high prolactin hormone levels $>208.5 \mathrm{ng} / \mathrm{ml}$

Table 3: Respondents distribution according to frequency of prolactin hormone oxytocin massage method and Mamet massage method

\begin{tabular}{llllll}
\hline Prolactin hormone level & \multicolumn{3}{l}{ Method } & & \\
\cline { 2 - 3 } & Oxytocin massage & & Massage Mamet \\
\cline { 2 - 3 } & Frequency & $\%$ & & Frequency & $\%$ \\
\hline Normal $(9.7-208.5 \mathrm{ng} / \mathrm{ml})$ & 9 & & & 14 & 87.5 \\
High $(>208.5 \mathrm{ng} / \mathrm{ml})$ & 7 & 3.8 & & 14 & \\
\hline
\end{tabular}




\section{Bivariate analysis}

After doing the characteristics of each variable in this study, the analysis continued at the bivariate level. To know the relationship (correlation) between the independent variable with the dependent variable we used bivariate analysis. Analysis of the data used to see the relationship between the independent and dependent variables with the use of the independent t-test. Independent test t-test is used to estimate the difference in the effectiveness of oxytocin and Mamet massage on prolactin hormone levels for smooth milk in postpartum mothers. Significant level $(\alpha=0.05)$ guidelines in accepting the hypothesis: If the value of $p$ $<0.05$ then $\mathrm{HO}$ is rejected, if the value of $\mathrm{p}>0.05$ then $\mathrm{HO}$ fails to be rejected. Before the independent t-test in this study, the parametric prerequisite test for normality and homogeneity was tested.

\section{Normality test}

A normality test is used to see whether the data are normally distributed or not. In this test, the ShapiroWilk test was used, the following results were obtained:

Table 4: Normality tests on respondents for prolactin hormone levels for smooth breast milk oxytocin and marble massage methods

\begin{tabular}{lll}
\hline Group & Pretest & Distribution \\
\hline Prolactin hormone oxytocin massage method & 0.423 & Normal \\
Prolactin hormone levels in the Mamet massage method & 0.426 & Normal \\
\hline
\end{tabular}

The Shapiro-Wilk test results above show that all data on the prolactin hormone levels of the oxytocin and Mamet massage method for the smoothness of breast milk have a normal distribution with $p>0.05$ (Table 4).

\section{Homogeneity test}

Homogeneity tests were also performed using the Levene Test to find out whether the data had the same variance or not (homogeneous).

Table 5 appears that all data have unequal variants (not homogeneous) as evidenced by the significant value or probability $0.006(p<0.05)$.

Table 5: Homogeneity test on respondents of prolactin hormone levels for smooth breastfeeding using oxytocin and Mamet massage methods in work areas of Langsa city health office

\begin{tabular}{llll}
\hline Group & Levene statistic & Sig. & Data \\
\hline Prolactin hormone oxytocin and Mamet & 8.933 & 0.006 & No Homogen
\end{tabular}

massage methods

Table 6 is known that the average oxytocin massage method is $195.6 \mathrm{ng} / \mathrm{ml}$ with Std. deviation

Table 6: Results of independent tests of prolactin hormone t-tests for smooth breastfeeding using oxytocin and Mamet massage methods in the work areas of Langsa city health office

\begin{tabular}{llllll}
\hline Characteristics (variables) & Mean & Std. Deviation & Std. error mean & p-value & $\mathrm{n}$ \\
\hline Prolactin hormone level & & & & & \\
$\quad$ Oxytocin massage method & 195.694 & 106.8814 & 26.7204 & 0.000 & 32 \\
Mamet massage method & 538.925 & 269.5994 & 67.3999 & & \\
\hline
\end{tabular}

$106.8 \mathrm{ng} / \mathrm{ml}$. The average method for massage of guinea pigs is $538.9 \mathrm{ng} / \mathrm{ml}$ with Std. deviation $269.6 \mathrm{ng} / \mathrm{ml}$. While the results of the independent t-test statistical test showed that the levels of the hormone prolactin for the smoothness of breast milk value of $p=0.000$, it can be concluded that there are significant differences between the oxytocin and Mamet massage methods.

\section{Discussion}

Oxytocin and Mamet massage are massaging techniques aimed at stimulating the breast so that the breast comes out more optimally. The two steps are widely used by postpartum mothers to stimulate the outflow of breast milk. The results of the study note that there are differences in the effectiveness of oxytocin and Mamet massage on the levels of the hormone Prolactin for smooth milk in Postpartum Mothers in the health service of Langsa City. The Mamet massage method has an average of $538.9 \mathrm{ng} / \mathrm{ml}$ Std. deviation $269.6 \mathrm{ng} / \mathrm{ml}$ in the smoothness of breast milk, while the oxytocin massage method has an average of $195.6 \mathrm{ng} / \mathrm{ml}$ with Std. deviation $106.8 \mathrm{ng} / \mathrm{ml}$ smooth milk. Independent t-test statistical test results obtained levels of the hormone prolactin for smooth milk $p=0.000$.

It can be concluded that there are significant differences between the oxytocin and Mamet massage methods. Respondents using oxytocin massage method with the highest prolactin hormone level were $357.9 \mathrm{ng} / \mathrm{ml}$ and the lowest prolactin hormone level was $29.8 \mathrm{ng} / \mathrm{ml}$. While respondents with the method of massage of the highest prolactin hormone levels of $1178.0 \mathrm{ng} / \mathrm{ml}$ and the lowest levels of the hormone prolactin of $160.9 \mathrm{ng} / \mathrm{ml}$. Mamet technique is more optimal in smooth milk. Mamet massage techniques are more effective than breast milk pumps [13]. Mamet massage is more effective in stimulating the pituitary and secreting the hormones prolactin and oxytocin early in breastfeeding. With the Mamet massage method, it will affect the vegetative nerves and subcutaneous tissue which can relax the tissues, thereby facilitating blood flow in the ductal system.

Mamet massage interventions are more effective in stimulating the anterior and posterior pituitary secreting the hormones prolactin and oxytocin early in breastfeeding. Oxytocin and prolactin stimulate milk production and milk production during breastfeeding [14]. In other studies, it was found that breast massage only causes the removal of breast milk that has been stored in breast milk and the release of prolactin does not associate with increased levels of oxytocin [15]. Lack of breast milk volume in the $1^{\text {st }}$ day after birth can be caused by a lack of stimulation of the hormones prolactin and oxytocin which are very instrumental in the process of producing and releasing 
milk. Under certain conditions, massage can be done to stimulate the oxytocin system, reduce pain and stress, and improve brain development [16].

The general condition experienced by postpartum mothers is due to a lack of experience and psychological changes that can affect the work of the hormones prolactin and oxytocin. Women generally stop inadequate milk production as their reason for early supplementation, which endangers the purpose of breastfeeding [17]. In addition, age and nutrition factors affect milk production. Psychological conditions also affect breastfeeding, such as stress, emotional instability, lack of family, or partner affecting milk production [4]. Other than that other causes are concerns that breastfeeding is not enough to meet the needs of infants, as well as changes in maternal attainment, especially for mothers who have had babies for the first time [18].

\section{Conclusion}

There are differences in the effectiveness of oxytocin and Mamet massage on the prolactin hormone levels for smooth milk. Mamet massage is more effective at increasing the smoothness of breast milk. The average level of the prolactin hormone, the oxytocin massage method was $195.6 \mathrm{ng} / \mathrm{ml}$ with Std. deviation $106.8 \mathrm{ng} / \mathrm{ml}$ while the average method of massage the Mamet is $538.9 \mathrm{ng} / \mathrm{ml}$ with Std. deviation $269.6 \mathrm{ng} / \mathrm{ml}$. Independent t-test results obtained levels of the hormone prolactin hormone levels for a smooth breast milk $p=0.000$.

\section{References}

1. Dinas Kesehatan Kota Langsa. Data Kesehatan Masyarakat. Indonesia: Dinas Kesehatan Kota Langsa; 2018.

2. Pascale KN, Laure NJ, Enyong OJ. Factors associated with breast feeding as well as the nutritional status of infants (0-12) months: An epidemiological study in yaounde, Cameroon. Pak J Nutr. 2007;6(3):259-63. https://doi.org/10.3923/ pjn.2007.259.263

3. Bentley ME, Dee DL, Jensen JL. Breastfeeding among low income, African-American women: power, beliefs and decision making. J Nutr. 2003;133(1):305S-9. https://doi.org/10.1093/ jn/133.1.305s

PMid: 12514315

4. Girma W. Ganebo T. Determinants of Nutrition status of Women and Children in Ethiopia. Calverton, Maryland, USA: ORC Macro; 2002.
5. Pace B. Breastfeeding. J Am Med Assoc. 2001;286(3):374.

6. Field T. Massage therapy research review. Complement Ther Clin Pract. 2014;20(4):224-9.

PMid:25172313

7. Kim IH, Kim TY, Ko YW. The effect of a scalp massage on stress hormone, blood pressure, and heart rate of healthy female. $\mathrm{J}$ Phys Ther Sci. 2016;28(10):2703-7. https://doi.org/10.1589/ jpts.28.2703

PMid:27821918

8. Turkeltaub PC, Yearwood EL, Friedmann E. Effect of a brief seated massage on nursing student attitudes toward touch for comfort care. J Altern Complement Med. 2014;20(10):792-9. https://doi.org/10.1089/acm.2014.0142

PMid:25140587

9. Bahrami T, Rejeh N, Heravi-Karimooi M, Tadrisi SD, Vaismoradi $M$. The effect of foot reflexology on hospital anxiety and depression in female older adults: A randomized controlled trial. Int J Ther Massage Bodywork. 2019;12(3):16-21. https://doi. org/10.3822/ijtmb.v12i3.429

PMid:31489059

10. Hegar H. Saku Menejemen Laktasi. Jakarta: EGC Depkes RI; 2011.

11. Biancuzzo M. Breastfeeding the Newborn: Clinical Strategies for Nurses. St Louis: Mosby; 2003.

12. Gomes M, Trocado V, Carlos-Alves M, Arteiro D, Pinheiro P. Intrapartum synthetic oxytocin and breastfeeding: Aretrospective cohort study. J Obstet Gynaecol. 2018;38(6):745-9. https://doi. org/10.1080/01443615.2017.1405924 PMid:29523035

13. Matthiesen AS, Ransjö-Arvidson AB, Nissen E, Uvnäs-Moberg K Postpartum maternal oxytocin release by newborns: Effects of infant hand massage and sucking. Birth. 2001;28(1):13-9. https://doi.org/10.1046/j.1523-536x.2001.00013.x PMid: 11264623

14. Jonas K, Johansson LM, Nissen E, Ejdebäck M, RansjöArvidson AB, Uvnäs-Moberg K. Effects of intrapartum oxytocin administration and epidural analgesia on the concentration of plasma oxytocin and prolactin, in response to suckling during the second day postpartum. Breastfeed Med. 2009;4(2):71-82. https://doi.org/10.1089/bfm.2008.0002

PMid:19210132

15. Yokoyama $\mathrm{Y}$, Ueda T, Irahara M, Aono T. Releases of oxytocin and prolactin during breast massage and suckling in puerperal women. Eur J Obstet Gynecol Reprod Biol. 1994;53(1):17-20. https://doi.org/10.1016/0028-2243(94)90131-7 PMid:8187915

16. Filippa M, Poisbeau $\mathrm{P}$, Mairesse J, Monaci MG, Baud $\mathrm{O}$, Hüppi $\mathrm{P}$, et al. Pain, parental involvement, and oxytocin in the neonatal intensive care unit. Front Psychol. 2019;10:715. https://doi.org/10.3389/fpsyg.2019.00715 PMid:31001173

17. Erickson EN, Lee CS, Emeis CL. Role of prophylactic oxytocin in the third stage of labor: Physiologic versus pharmacologically influenced labor and birth. J Midwifery Womens Health. 2017;62(4):418-24. https://doi.org/10.1111/jmwh.12620 PMid:28703925

18. Chung L, Hung L, Kuo S, Huang C. Effects of LI4 and BL 67 acupressure on labor pain and uterine contractions in the first stage of labor. J Nurs Res. 2003;11(4):251-60. https://doi. org/10.1097/01.jnr.0000347644.35251.c1

PMid:14685931 